\title{
Preparation and Characterization of High-Strength Glass-Ceramics via Ion-Exchange Method
}

\author{
Jianwei Lu ${ }^{1,2,+}$, Haifeng Wang ${ }^{1,2,+}$, Juanjuan Zhu ${ }^{1}$, Qiuju Zheng ${ }^{3}$, Linfeng Ding ${ }^{1,2, *}$ and Weizhong Jiang ${ }^{1,2, *}$ \\ 1 State Key Laboratory for Modification of Chemical Fibers and Polymer Materials, College of Materials Science \\ and Engineering, Donghua University, Shanghai 201620, China; jwlu@mail.dhu.edu.cn (J.L.); \\ whf2008@dhu.edu.cn (H.W.); zhujuanjuan@dhu.edu.cn (J.Z.) \\ 2 Engineering Research Center of Advanced Glass Manufacturing Technology, Ministry of Education, Donghua \\ University, Shanghai 201620, China \\ 3 School of Materials Science and Engineering, Qilu University of Technology (Shandong Academy of Sciences), \\ Jinan 250353, China; qlzhengqj@163.com \\ * Correspondence: linfeng.ding@dhu.edu.cn (L.D.); jwzh@dhu.edu.cn (W.J.) \\ + These authors contributed equally.
}

Citation: Lu, J.; Wang, H.; Zhu, J.; Zheng, Q.; Ding, L.; Jiang, W.

Preparation and Characterization of High-Strength Glass-Ceramics via Ion-Exchange Method. Materials 2021 14, 5477. https://doi.org/10.3390/ ma14195477

Academic Editor: Chiara

Vitale-Brovarone

Received: 14 August 2021

Accepted: 20 September 2021

Published: 22 September 2021

Publisher's Note: MDPI stays neutral with regard to jurisdictional claims in published maps and institutional affiliations.

Copyright: (c) 2021 by the authors. Licensee MDPI, Basel, Switzerland. This article is an open access article distributed under the terms and conditions of the Creative Commons Attribution (CC BY) license (https:/ / creativecommons.org/licenses/by/ $4.0 /)$.

\begin{abstract}
Lithium aluminosilicate glass-ceramics (LAS GCs) are ideal shell materials for mobile phones; however, the mechanical properties of LAS GCs are comparatively lower than that of other shell materials. In this work, the impact of $\mathrm{TiO}_{2} /\left(\mathrm{TiO}_{2}+\mathrm{ZrO}_{2}\right)$ ratio on properties of LAS GCs was studied and the ion-exchange methods were applied to improve the mechanical properties of LAS GCs. The results show that LAS GCs with $\mathrm{TiO}_{2} /\left(\mathrm{TiO}_{2}+\mathrm{ZrO}_{2}\right)=1 / 2$ exhibit the best flexural strength $(109 \mathrm{MPa})$ and Vickers hardness $\left(525 \mathrm{Kg} / \mathrm{mm}^{2}\right)$. The as-prepared glass was nucleated at $560{ }^{\circ} \mathrm{C}$ for $1 \mathrm{~h}$ and crystallized at $720^{\circ} \mathrm{C}$ for $0.5 \mathrm{~h}$. The main crystalline phases of LAS GCs are $\beta$-quartz solid solution, $\beta$-spodumene solid solution, and $\mathrm{Li}_{2} \mathrm{SiO}_{3}$. Moreover, the flexural strength and Vickers hardness of LAS GCs with $\mathrm{TiO}_{2} /\left(\mathrm{TiO}_{2}+\mathrm{ZrO}_{2}\right)=1 / 2$ further increased to $356 \mathrm{MPa}$ and $838 \mathrm{Kg} / \mathrm{mm}^{2}$ after an ion-exchange at $420{ }^{\circ} \mathrm{C}$ for $6 \mathrm{~h}$ in pure $\mathrm{KNO}_{3}$ molten salt. The LAS GCs with enhanced mechanical strength have the potential to be applied as mobile phone back panels.
\end{abstract}

Keywords: glass-ceramics; ion-exchange; mechanical properties; structure

\section{Introduction}

Glass-ceramics (GCs) are inorganic materials with dense structure composed of microcrystalline phase and residual glass [1,2]. They combine the excellent properties of glass and ceramics. The desired properties of GCs can be obtained by adjusting the chemical composition, distribution, and proportion of crystals and glass phases [3,4]. With the development of $5 \mathrm{G}$ communication and wireless charging technology, the requirements of terminal equipment for shell materials are stringent [5]. Due to the drawbacks of metal in shielding signals, GCs could be a better choice as shell materials for consumer electronic devices [6].

During the preparation of GCs, the selection of nucleating agents (such as $\mathrm{TiO}_{2}, \mathrm{ZrO}_{2}$, or both of them) and the control of heat treatment process may change the type and content of the main crystal phase, thus affecting the thermal expansion and mechanical properties of GCs [7-9]. With proper nucleating agents and heat treatment, the performance of GCs can be designed by controlled crystallization.

$\mathrm{Li}_{2} \mathrm{O}-\mathrm{Al}_{2} \mathrm{O}_{3}-\mathrm{SiO}_{2}$ (LAS) GCs have low coefficient of thermal expansions (CTE) and high mechanical properties due to the crystalline phases formed during thermal treatment $[10,11]$. The existence of crystal and glass-crystal interface makes the crack propagation pathway in GCs different from their parent glass [12-14]. Deng et al. [15] studied the influence of different microstructures on the crack propagation of GCs through molecular dynamics simulation, and they found that the crack propagation mode was related to the 
size, aspect ratio, and alignment angle of crystalline phases. Serbena et al. [16] prepared GCs with different crystallinity by controlling the heat treatment processes. With the increase in crystallinity from 0 to $100 \%$, the mechanical properties of samples are constantly improved. They believe that the main toughening mechanisms are crack deflection and bowing and bridging caused by thermal expansion mismatch between the $\mathrm{Li}_{2} \mathrm{O}-2 \mathrm{SiO}_{2}$ crystal phase and residual glass. Li et al. [17] studied the effect of crystal size on the mechanical strength of lithium disilicate GCs. They concluded that the "interlocking effect" caused by larger-sized crystals and the "micro residual stress effect" correlated with the CTE mismatch between glass matrix and crystals simultaneously determine the flexural strength of GCs.

However, the mechanical properties of GCs still show room for improvement compared with some high-strength materials. Ion-exchange is one of the most effective methods to strengthen LAS GCs. The smaller ions on the LAS GCs surface are replaced by the larger ions in the molten salt, and then a compressive stress layer is formed on the LAS GCs surface, which greatly improves its mechanical strength $[18,19]$. For example, K. Laczka et al. [20] prepared the GCs with lithium disilicate and lithium aluminosilicate as the main crystal phases through proper heat treatment and the flexural strength reached $300-450 \mathrm{MPa}$. After an ion-exchange in $\mathrm{KNO}_{3}$ salt bath at $400-420{ }^{\circ} \mathrm{C}$ for 9 or $16 \mathrm{~h}$, a surface compressive stress layer of about $15-20 \mu \mathrm{m}$ was formed due to the exchange of potassium and sodium ions, which improved almost $100 \%$ of the mechanical resistance.

Based on the literature [21-24], the composition of glass, the consist of molten salt, and the temperature and duration of ion-exchange will influence the ion-exchange process. Thus, it is necessary to design the best ion-exchange temperature and duration according to the specific composition of LAS GCs to prepare GCs with excellent mechanical properties.

In this paper, the effects of $\mathrm{TiO}_{2} /\left(\mathrm{TiO}_{2}+\mathrm{ZrO}_{2}\right)$ ratio on the structure and properties of LAS GCs were investigated, and the mechanical strength of LAS GCs was further improved by the ion-exchange method. We developed a new glass-ceramic for shell materials of portable electronic devices.

\section{Experiment Procedures}

\subsection{Sample Preparation}

The following reagent-grade raw materials were used to make glasses (Sinopharm Chemical Reagent Co. Ltd., Shanghai, China): $\mathrm{Li}_{2} \mathrm{CO}_{3}, \mathrm{Al}_{2} \mathrm{O}_{3}, \mathrm{SiO}_{2}, \mathrm{MgCO}_{3}, \mathrm{Na}_{2} \mathrm{CO}_{3}$, $\mathrm{ZnO}, \mathrm{TiO}_{2}, \mathrm{ZrO}_{2}, \mathrm{NaNO}_{3}, \mathrm{KNO}_{3}$. The parent glass compositions with different $\mathrm{TiO}_{2} /$ $\left(\mathrm{TiO}_{2}+\mathrm{ZrO}_{2}\right)$ ratios are shown in Table 1. Firstly, the raw materials were melted in a quartz crucible at $1450{ }^{\circ} \mathrm{C}$ for $4 \mathrm{~h}$ in a furnace with $\mathrm{MoSi}_{2}$ heating elements (SLQ 1700, Shanghai, China). The melt was cast into a preheated iron mold to obtain a glassy block. Finally, the formed glass was annealed at $450{ }^{\circ} \mathrm{C}$ for $2 \mathrm{~h}$.

Table 1. Compositions (in wt $\mathrm{w}$ ) and properties of the LAS GCs samples.

\begin{tabular}{|c|c|c|c|c|c|c|c|c|c|c|c|}
\hline Sample & $\mathrm{SiO}_{2}$ & $\mathrm{Li}_{2} \mathrm{O}$ & $\mathrm{Al}_{2} \mathrm{O}_{3}$ & $\mathrm{Na}_{2} \mathrm{O}$ & $\mathrm{TiO}_{2}$ & $\mathrm{ZrO}_{2}$ & Others & $\begin{array}{c}H V \\
\left(\mathrm{Kg} / \mathrm{mm}^{-2}\right)\end{array}$ & $\begin{array}{c}\text { Flexural } \\
\text { Strength (MPa) }\end{array}$ & $\mathrm{CI} \%$ & Transparency \\
\hline T0 & 70 & 12.4 & 7.4 & 2.8 & 0 & 4 & 3.4 & $520 \pm 21$ & $86 \pm 15$ & 47 & Transparent \\
\hline $\mathrm{T} 1$ & 70 & 12.4 & 7.4 & 2.8 & 1 & 3 & 3.4 & $528 \pm 18$ & $101 \pm 11$ & 54 & Translucent \\
\hline $\mathrm{T} 2$ & 70 & 12.4 & 7.4 & 2.8 & 2 & 2 & 3.4 & $525 \pm 17$ & $109 \pm 17$ & 64 & Opaque \\
\hline T3 & 70 & 12.4 & 7.4 & 2.8 & 3 & 1 & 3.4 & $503 \pm 18$ & $96 \pm 16$ & 45 & Opaque \\
\hline $\mathrm{T} 4$ & 70 & 12.4 & 7.4 & 2.8 & 4 & 0 & 3.4 & $490 \pm 25$ & $81 \pm 14$ & 51 & Opaque \\
\hline
\end{tabular}

The LAS GCs were prepared based on the measurements of T2 sample by differential scanning calorimetry (DSC, STA 449F3, Netzsch, Selb, Germany) and rotary viscometry (RSV 1600, Orton, Westerville, OH, USA). As shown in Figure 1, the viscosity-temperature curve was fitted by the MYEGA equation [25] and the glass transition temperature ( $T_{\mathrm{g}}$ ) was obtained from the DSC method [26]. The viscosity-temperature curve provides references for the future production process. The T0-T4 specimens were nucleated at $560^{\circ} \mathrm{C}\left(\sim 100{ }^{\circ} \mathrm{C}\right.$ higher than $T_{\mathrm{g}}$ ) for $1 \mathrm{~h}$ and crystallized (around crystallization peak $T_{\mathrm{c}}$ ) at $720^{\circ} \mathrm{C}$ for $0.5 \mathrm{~h}$ 
to obtain LAS GCs. The prepared T2 LAS GCs were further immersed in a molten $\mathrm{KNO}_{3}$ salt bath at $400-440{ }^{\circ} \mathrm{C}$ for different durations $(2,4,6,8$, and $10 \mathrm{~h})$.

\subsection{Characterization}

The crystalline phases of samples were identified by X-ray diffraction (XRD, D/max2500PC, Rigaku, Tokyo, Japan). The amount of the crystalline phases (crystallized volume fraction) was determined according to the procedure used by Daguano et al. [27]. The Crystallinity Index, CI\%, was calculated from the following equation:

$$
C I \%=\left(\frac{A_{c}}{A_{T}}\right) \times 100 \%
$$

where $A_{c}$ is the crystalline area, $A_{T}\left(A_{T}=\right.$ amorphous + crystalline $)$ is the total area.

The structure of the glass was characterized with a Fourier transform infrared spectrometer (FT-IR, Nicolet 8700, Madison, WI, USA). The CTE of LAS GCs was measured with a dilatometer (DIL 402C, Netzsch, Selb, Germany). The flexural strength of the samples was tested using a universal testing machine (WDW-20KN, Changchun, China) with a cross-head speed of $0.5 \mathrm{~mm} / \mathrm{min}$. Vickers hardness $(H V)$ of the samples was tested using a microhardness tester (MHV-2000S, Shanghai, China) with a load of $0.098 \mathrm{~N}$ for a dwell time of $12 \mathrm{~s}$. The concentration distributions of $\mathrm{K}^{+}$and $\mathrm{Na}^{+}$ions on the surface of LAS GCs after ion-exchange was evaluated by EDS (X-Max 50, Oxford Instruments, Oxford, UK).

(a)

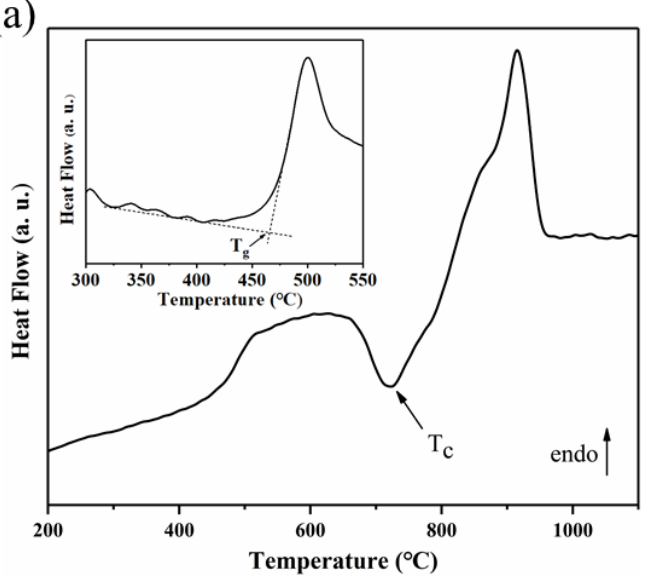

(b)

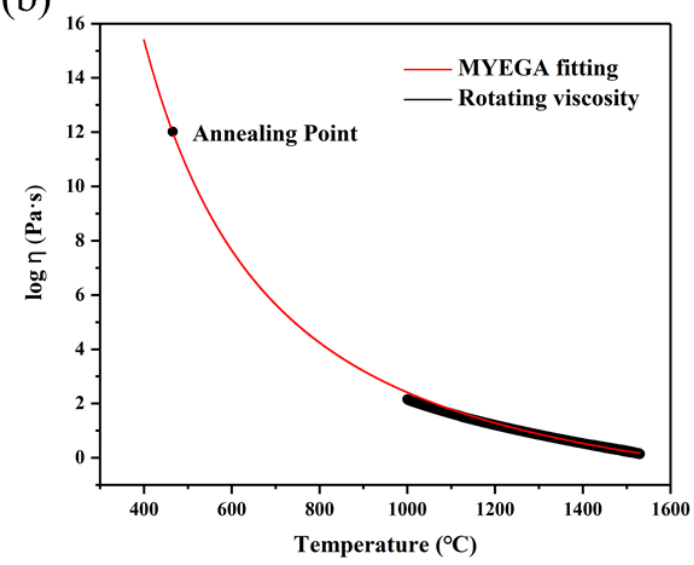

Figure 1. (a) The first DSC upscan curve of the $\mathrm{T} 2$ parent glass sample at a heating rate of $20 \mathrm{~K} / \mathrm{min}$. The insert figure is the second upscan curve followed by a cooling rate of $10 \mathrm{~K} / \mathrm{min}$ (to determine $T_{\mathrm{g}}$ ); (b) viscosity of T2 parent glass sample measured by the rotation method. The viscosity data were fitted by the MYEGA equation.

\section{Results and Discussion}

\subsection{Effect of $\mathrm{TiO}_{2} /\left(\mathrm{TiO}_{2}+\mathrm{ZrO}_{2}\right)$ Ratio on Properties of LAS GCs}

It can be seen in Table 1 that the flexural strength of LAS GCs first increases from $86 \mathrm{MPa}$ to $109 \mathrm{MPa}$ with the increase in $\mathrm{TiO}_{2} /\left(\mathrm{TiO}_{2}+\mathrm{ZrO}_{2}\right)$ ratio, and then decreases to $81 \mathrm{MPa}$ when the content of $\mathrm{TiO}_{2}$ reached $4 \mathrm{wt} \%$. The $H V$ of LAS GCs shows a similar trend to the flexural strength. Moreover, the samples change from transparent to opaque with the increase in $\mathrm{TiO}_{2} /\left(\mathrm{TiO}_{2}+\mathrm{ZrO}_{2}\right)$ ratio.

The main reasons for the great mechanical properties of LAS GCs prepared in this work are due to the crystal species and the microstructure of GCs. The XRD results in Figure 2 show that the main crystalline phases of T0-T4 LAS GCs are $\beta$-quartz solid solution ( $\mathrm{LiAlSi}_{2} \mathrm{O}_{6}$, PDF 74-1095), $\beta$-spodumene ( $\mathrm{LiAlSi}_{3} \mathrm{O}_{8}$, PDF 35-794) solid solution, and lithium metasilicate $\left(\mathrm{Li}_{2} \mathrm{SiO}_{3}, \mathrm{PDF} 72-1140\right)$. The existence of $\beta$-quartz and $\beta$-spodumene solid solutions leads to the low CTEs of LAS GCs samples compared with conventional glasses and ceramics (e.g., the CTE of T2 sample is $3.3 \times 10^{-6}{ }^{\circ} \mathrm{C}^{-1}$ ). This low CTE is also crucial in electronic applications, especially when the heat dissipation is significant (e.g., wireless charging). 
The peak intensities of T0-T4 samples are different from each other, even though the peak positions are similar. As shown in Table 1, the $\mathrm{CI} \%$ of these samples ranges from $45 \%$ to $64 \%$, and reaches its maximum at the $\mathrm{TiO}_{2} /\left(\mathrm{TiO}_{2}+\mathrm{ZrO}_{2}\right)$ ratio equal to $1 / 2$. According to Bhattacharyya et al. [28], the $\mathrm{ZrTiO}_{4}$ crystal nucleus may be formed in the LAS GCs. The development of the $\mathrm{ZrTiO}_{4}$ crystals will enhance the heterogeneous nucleation and thus promote the crystallinity of the GC which, in turn, improved both the flexural strength and Vickers hardness [28,29].

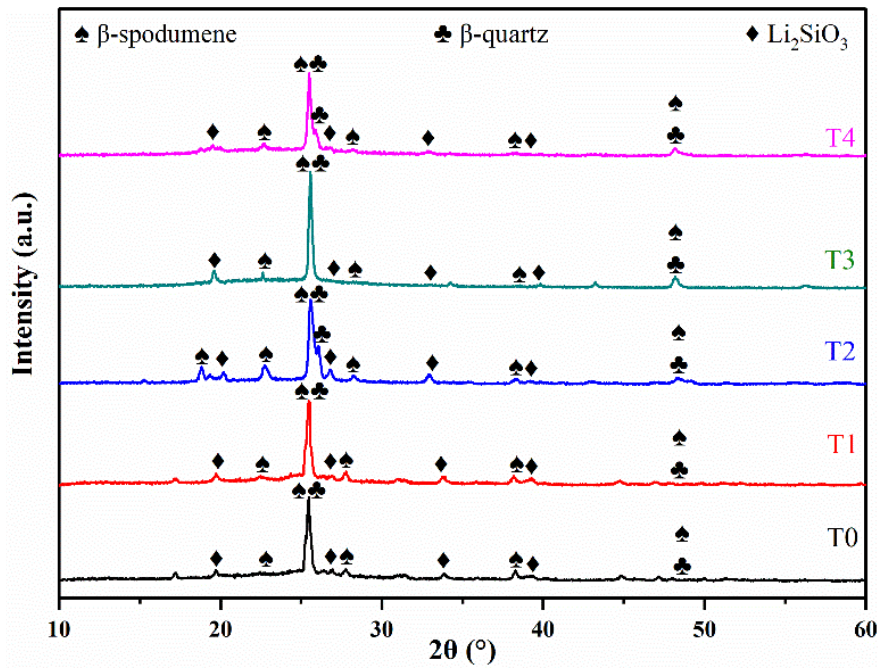

Figure 2. XRD patterns of T0-T4 LAS GCs.

To explore the microstructure, the FT-IR results of T0-T4 GCs are shown in Figure 3. The absorption peaks at $1020 \mathrm{~cm}^{-1} / 930 \mathrm{~cm}^{-1}, 850 \mathrm{~cm}^{-1}$, and $610 \mathrm{~cm}^{-1}$ after crystallization can be attributed to the asymmetric stretching vibrations of $\mathrm{Si}-\mathrm{O}-\mathrm{Si}(\mathrm{Al})$, the symmetric stretching vibrations of $\mathrm{Si}-\mathrm{O}-\mathrm{Si}$, and the bending vibration of $\mathrm{Si}-\mathrm{O}-\mathrm{Al}$, respectively [30-32]. As can be seen in Figure 3, the broad peaks at approximately $1020 \mathrm{~cm}^{-1}$ and $930 \mathrm{~cm}^{-1}$ shift toward the lowest wavenumbers when the $\mathrm{TiO}_{2} /\left(\mathrm{TiO}_{2}+\mathrm{ZrO}_{2}\right)$ ratio reaches $1 / 2$. The asymmetric stretching vibrations of $\mathrm{Si}-\mathrm{O}-\mathrm{Si}(\mathrm{Al})$ shifts to the lower wavenumbers when the glass network structure becomes stronger [33,34]; thus, this observation is consistent with the overall mechanical properties trend of T2 LAS GCs. Moreover, examining the XRD analysis, we find that both crystalline phases and glass network structure play important roles in the mechanical properties' evolution in LAS GCs.

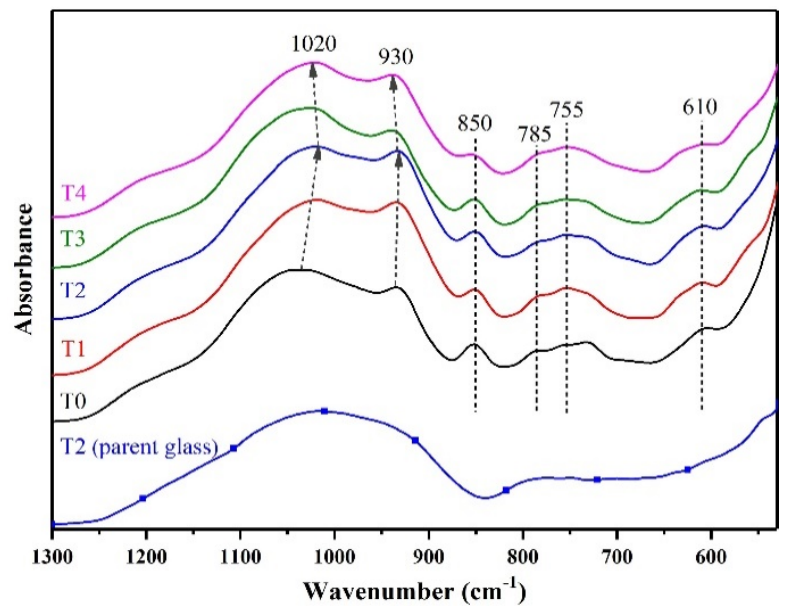

Figure 3. FT-IR of parent glass and T0-T4 LAS GCs. 


\subsection{Ion-Exchange Strengthening Process}

Figure 4 shows the flexural strength and Vickers hardness of the crystallized T2 sample (best mechanical properties) after ion-exchange at different temperatures and times. Obviously, ion-exchange improved the mechanical properties of LAS GCs. With the increase in ion-exchange temperature, it takes a shorter time to reach the highest mechanical properties. The mechanical properties of the $\mathrm{T} 2$ sample reach the best values after being ion-exchanged at $420^{\circ} \mathrm{C}$ for $6 \mathrm{~h}$, with the flexural strength of $356 \mathrm{MPa}$ and Vickers hardness equaling $838 \mathrm{Kg} / \mathrm{mm}^{2}$.

(a)

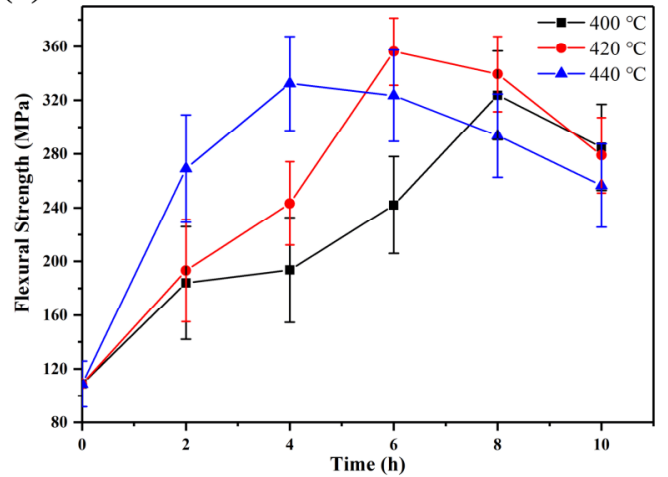

(b)

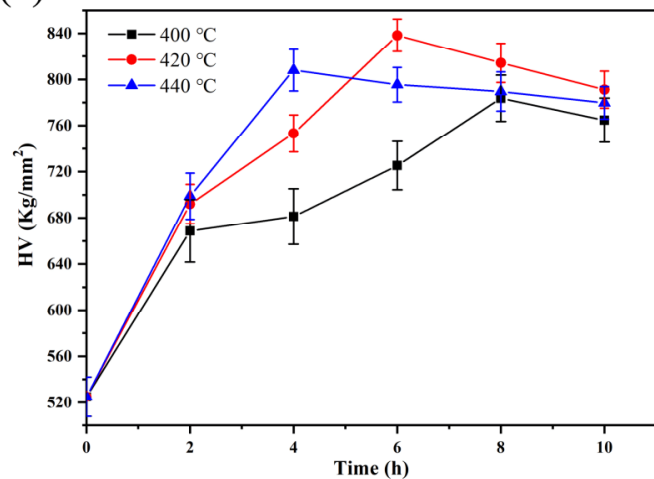

Figure 4. (a) Flexural strength and (b) Vickers hardness of T2 LAS GCs after ion-exchange at different temperatures for $2 \mathrm{~h}$.

These further enhanced mechanical properties are mainly attributed to the formation of the compressive stress layer on the glass surface. Figure 5 shows the $\mathrm{K}^{+}$and $\mathrm{Na}^{+}$ concentration distribution in T2 LAS GCs after ion-exchange at $420^{\circ} \mathrm{C}$ for $2 \mathrm{~h}$. The results show that the concentration of $\mathrm{K}^{+}$ions gradually decreases from $16.5 \mathrm{wt} \%$ (on the surface) to $0 \mathrm{wt} \%$ (deeper than $11.7 \mu \mathrm{m}$ inside glass body) after the ion-exchange process. Meanwhile, the concentration of $\mathrm{Na}^{+}$ions increases from $0 \mathrm{wt} \%$ (on the surface) to $2.7 \mathrm{wt} \%$ (deeper than $11.7 \mu \mathrm{m}$ inside glass body). Based on the glass compositions, it can be inferred that $\mathrm{Na}^{+}, \mathrm{K}^{+}$ and $\mathrm{Li}^{+}$ions were all involved in the ion-exchange process because of charge balancing before and after the exchange. The smaller $\mathrm{Li}^{+}$ions and $\mathrm{Na}^{+}$ions on the GCs surface were replaced by the larger $\mathrm{K}^{+}$ions from the molten salt, and a compressive stress layer was formed on the GCs surface, which prevents the surface crack from spreading inside to glass body under high stress $[18,35]$. During the ion-exchange, the exchange of $\mathrm{Na}^{+}$with $\mathrm{K}^{+}$ions dominate the formation of the compressive stress layer and the enhancement of mechanical properties [20].

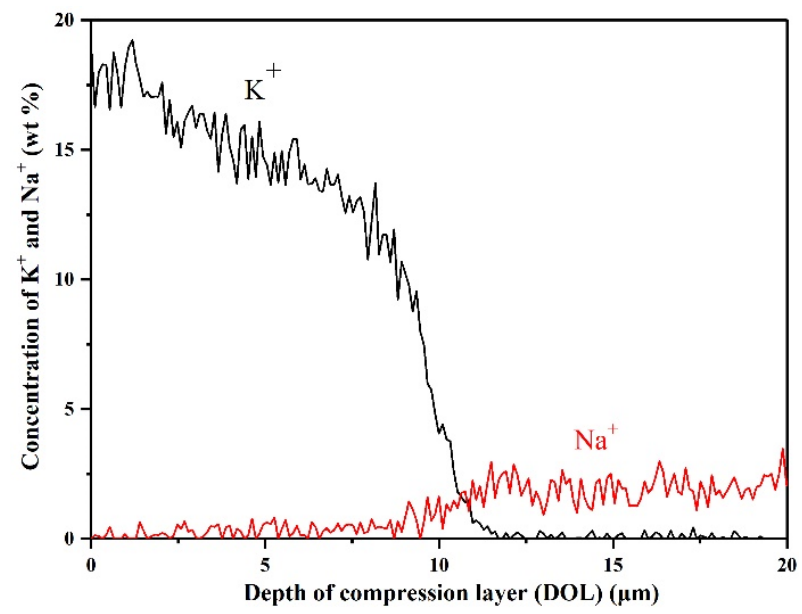

Figure $5 . \mathrm{K}^{+}$and $\mathrm{Na}^{+}$concentration distribution in T2 LAS GCs after ion-exchange at $420{ }^{\circ} \mathrm{C}$ for $2 \mathrm{~h}$. 
Moreover, the $\mathrm{K}^{+}$ions diffusion profiles of LAS GCs at $420{ }^{\circ} \mathrm{C}$ for different ionexchange times $(2,4,6,8$ and $10 \mathrm{~h})$ are shown in Figure 6. The concentration of $\mathrm{K}^{+}$ions on the surface of $\mathrm{T} 2$ sample is very high (above $17 \mathrm{wt} \%$ ), while it gradually decreases to $0 \mathrm{wt} \%$ and tends to be stable inside the glass sample. The depth of compression layer (DOL) for five different LAS GCs samples is from $\sim 10 \mu \mathrm{m}$ to $\sim 17 \mu \mathrm{m}$. As can be seen in Figure 4, the mechanical properties of the glass are positively correlated with the concentration distribution at the first $6 \mathrm{~h}$ of ion-exchange. However, the "stuffing effect" $[19,36]$ and stress relaxation of the glass structure happened afterward [37]; consequently, the mechanical properties reached the optimal at ion-exchange for $6 \mathrm{~h}$ at $420^{\circ} \mathrm{C}$. When the ion-exchange duration exceeded $6 \mathrm{~h}$, the stress relaxation effect is dominant in the LAS GCs sample [37], and the mechanical strength of GCs starts to decrease.

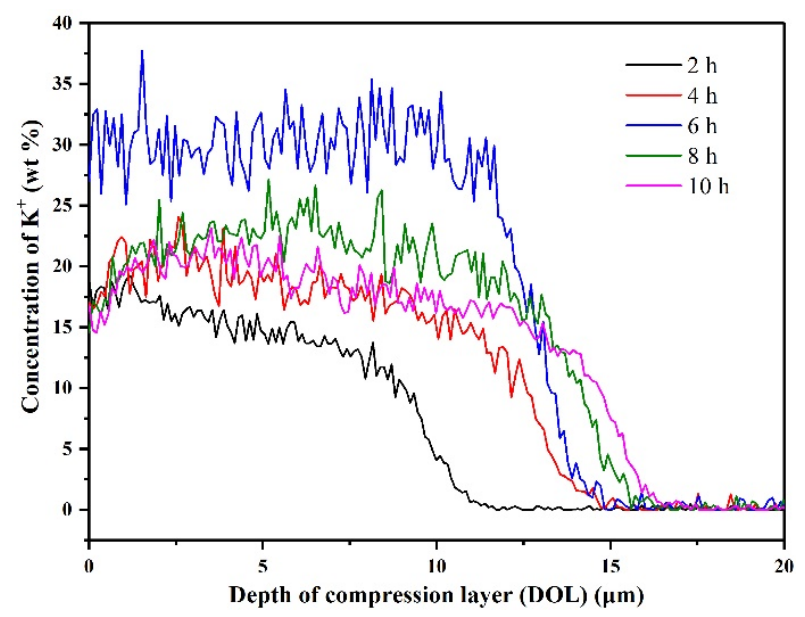

Figure $6 . \mathrm{K}^{+}$concentration distribution in T2 LAS GCs at $420^{\circ} \mathrm{C}$ for different ion-exchange times.

\section{Conclusions}

In this study, ion-exchanged LAS GCs with high mechanical performance were prepared. The results indicate that LAS GCs with $2 \mathrm{wt} \% \mathrm{TiO}_{2}$ and $2 \mathrm{wt} \% \mathrm{ZrO}_{2}$, nucleated at $560{ }^{\circ} \mathrm{C}$ for $1 \mathrm{~h}$, and crystallized at $720^{\circ} \mathrm{C}$ for $0.5 \mathrm{~h}$, exhibit the best flexural strength $(109 \mathrm{MPa})$ and Vickers hardness $\left(525 \mathrm{Kg} / \mathrm{mm}^{2}\right)$. The main crystal phases of the prepared LAS GCs are $\beta$-quartz solid solution, $\beta$-spodumene solid solution, and lithium metasilicate. Eventually, the flexural strength and Vickers hardness further increased almost 3 times and 1.6 times after an ion-exchange at $420^{\circ} \mathrm{C}$ for $6 \mathrm{~h}$.

Author Contributions: Conceptualization, J.L. and H.W.; methodology, H.W. and W.J.; software, J.L. and L.D.; validation, J.L., H.W. and L.D.; formal analysis, J.L. and H.W.; investigation, J.Z. and Q.Z.; resources, H.W. and L.D.; data curation, J.L., H.W. and J.Z.; writing-original draft preparation, J.L. and L.D; writing-review and editing, H.W., L.D. and Q.Z.; visualization, J.L. and L.D.; supervision, H.W. and W.J.; funding acquisition, L.D., H.W. and W.J. All authors have read and agreed to the published version of the manuscript.

Funding: This research was funded by the Fundamental Research Funds for the Central Universities (No. 2232021D-04, 2232021G-07) and the Open Fund of the State Key Laboratory of Luminescent Materials and Devices (South China University of Technology).

Institutional Review Board Statement: Not applicable.

Informed Consent Statement: Not applicable.

Data Availability Statement: The data presented in this study are available on request from the corresponding author.

Conflicts of Interest: The authors declare no conflict of interest. 


\section{References}

1. Soares, V.O.; Serbena, F.C.; Oliveira, G.D.; da Cruz, C.; Muniz, R.F.; Zanotto, E.D. Highly translucent nanostructured glass-ceramic. Ceram. Int. 2021, 47, 4707-4714. [CrossRef]

2. Deubener, J.; Allix, M.; Davis, M.J.; Duran, A.; Höche, T.; Honma, T.; Komatsu, T.; Krüger, S.; Mitra, I.; Müller, R.; et al. Updated definition of glass-ceramics. J. Non-Cryst. Solids 2018, 501, 3-10. [CrossRef]

3. Zanotto, E.D. A bright future for glass-ceramics. Am. Ceram. Soc. Bull. 2010, 89, 19-27.

4. Ritzberger, C.; Apel, E.; Holand, W.; Peschke, A.; Rheinberger, V.M. Properties and Clinical Application of Three Types of Dental Glass-Ceramics and Ceramics for CAD-CAM Technologies. Materials 2010, 3, 3700-3713. [CrossRef]

5. Wang, S.A.F.E.; Lai, B.C.; Hsu, Y.F.; Lu, C.A. Dielectric properties of $\mathrm{CaO}-\mathrm{B}_{2} \mathrm{O}_{3}-\mathrm{SiO}_{2}$ glass-ceramic systems in the millimeter-wave frequency range of 20-60 GHz. Ceram. Int. 2021, 47, 22627-22635. [CrossRef]

6. Guo, Y.L.; Liu, C.; Wang, J.; Ruan, J.; Li, X.Y.; Han, J.J.; Xie, J. Effect of $\mathrm{ZrO}_{2}$ crystallization on ion exchange properties in aluminosilicate glass. J. Eur. Ceram. Soc. 2020, 40, 2179-2184. [CrossRef]

7. Wang, J.; Cheng, J.S.; Tang, L.Y.; Tian, P.J. Effect of nucleating agents and heat treatments on the crystallization of magnesium aluminosilicate transparent glass-ceramics. J. Wuhan Univ. Technol. 2013, 28, 69-72. [CrossRef]

8. Hu, A.M.; Li, M.; Mao, D.L. Controlled crystallization of glass-ceramics with two nucleating agents. Mater. Charact. 2009, 60, 1529-1533. [CrossRef]

9. Dressler, M.; Rudinger, B.; Deubener, J. Crystallization kinetics in a lithium alumosilicate glass using $\mathrm{SnO}_{2}$ and $\mathrm{ZrO}_{2}$ additives. $J$. Non-Cryst. Solids 2014, 389, 60-65. [CrossRef]

10. Lilensten, L.; Fu, Q.; Wheaton, B.R.; Credle, A.J.; Stewart, R.L.; Kohli, J.T. Kinetic study on lithium-aluminosilicate (LAS) glass-ceramics containing MgO and ZnO. Ceram. Int. 2014, 40, 11657-11661. [CrossRef]

11. Dressler, M.; Rudinger, B.; Deubener, J. An In Situ High-Temperature X-Ray Diffraction Study of Early-Stage Crystallization in Lithium Alumosilicate Glass-Ceramics. J. Am. Ceram. Soc. 2011, 94, 1421-1426. [CrossRef]

12. Deng, B.; Luo, J.; Harris, J.T.; Smith, C.M. Critical stress map for $\mathrm{ZrO}_{2}$ tetragonal to monoclinic phase transformation in $\mathrm{ZrO}_{2}$-toughened glass-ceramics. Materialia 2020, 9, 100548. [CrossRef]

13. Deng, B.; Harris, J.T.; Luo, J. Atomic picture of crack propagation in $\mathrm{Li}_{2} \mathrm{O}-2 \mathrm{SiO}_{2}$ glass-ceramics revealed by molecular dynamics simulations. J. Am. Ceram. Soc. 2020, 103, 4304-4312. [CrossRef]

14. Maeda, K.; Iwasaki, K.; Urata, S.; Akatsuka, K.; Yasumori, A. 3D microstructure and crack pathways of toughened $\mathrm{CaO}_{-} \mathrm{Al}_{2} \mathrm{O}_{3}-$ $\mathrm{SiO}_{2}$ glass by precipitation of hexagonal $\mathrm{CaAl}_{2} \mathrm{Si}_{2} \mathrm{O}_{8}$ crystal. J. Am. Ceram. Soc. 2019, 102, 5535-5544. [CrossRef]

15. Deng, B.; Luo, J.; Harris, J.T.; Smith, C.M.; McKenzie, M.E. Molecular dynamics simulations on fracture toughness of $\mathrm{Al}_{2} \mathrm{O}_{3}-\mathrm{SiO}_{2}$ glass-ceramics. Scr. Mater. 2019, 162, 277-280. [CrossRef]

16. Serbena, F.C.; Mathias, I.; Foerster, C.E.; Zanotto, E.D. Crystallization toughening of a model glass-ceramic. Acta Mater. 2015, 86, 216-228. [CrossRef]

17. Li, D.; Guo, J.W.; Wang, X.S.; Zhang, S.F.; He, L. Effects of crystal size on the mechanical properties of a lithium disilicate glass-ceramic. Mater. Sci. Eng. A 2016, 669, 332-339. [CrossRef]

18. Beall, G.H.; Comte, M.; Dejneka, M.J.; Marques, P.; Pradeau, P.; Smith, C. Ion-Exchange in Glass-Ceramics. Front. Mater. 2016, 3 , 41. [CrossRef]

19. Guo, Y.; Wang, J.; Ruan, J.; Han, J.; Xie, J.; Liu, C. Microstructure and ion-exchange properties of glass-ceramics containing $\mathrm{ZnAl}_{2} \mathrm{O}_{4}$ and $\beta$-quartz solid solution nanocrystals. J. Eur. Ceram. Soc. 2021, 41, 5331-5340. [CrossRef]

20. Laczka, K.; Cholewa-Kowalska, K.; Sroda, M.; Rysz, J.; Marzec, M.M.; Laczka, M. Glass-ceramics of LAS $\left(\mathrm{Li}_{2} \mathrm{O}-\mathrm{Al}_{2} \mathrm{O}_{3}-\mathrm{SiO}_{2}\right)$ system enhanced by ion-exchange in $\mathrm{KNO}_{3}$ salt bath. J. Non-Cryst. Solids 2015, 428, 90-97. [CrossRef]

21. Torres-Castanon, J.J.; Gorokhovskii, A.V.; Zhabrev, V.A.; Fuentes, A.F.; Escalante-Garcia, J.I.; German, E.V. Kinetics and mechanism of the interaction of alkali calcium silicate glasses with salt melts in the $\mathrm{KNO}_{3}-\mathrm{Pb}\left(\mathrm{NO}_{3}\right)_{2}$ system. Glass Phys. Chem. 2004, 30, 167-172. [CrossRef]

22. Li, X.Y.; Jiang, L.B.; Wang, Y.; Mohagheghian, I.; Dear, J.P.; Li, L.; Yan, Y. Correlation between $\mathrm{K}^{+}-\mathrm{Na}^{+}$diffusion coefficient and flexural strength of chemically tempered aluminosilicate glass. J. Non-Cryst. Solids 2017, 471, 72-81. [CrossRef]

23. Karapetyan, G.O.; Loboda, V.V.; Tagantsev, D.K. Influence of ion exchange on liquid-liquid phase separation in alkali borosilicate glasses: Effect of ion-exchange-induced metastable glass homogenization. J. Non-Cryst. Solids 2000, 270, 154-162. [CrossRef]

24. Jiang, L.B.; Guo, X.T.; Li, X.Y.; Li, L.; Zhang, G.L.; Yan, Y. Different $\mathrm{K}^{+}-\mathrm{Na}^{+}$inter-diffusion kinetics between the air side and tin side of an ion-exchanged float aluminosilicate glass. Appl. Surf. Sci. 2013, 265, 889-894. [CrossRef]

25. Mauro, J.C.; Yue, Y.; Ellison, A.J.; Gupta, P.K.; Allan, D.C. Viscosity of Glass-Forming Liquids. Proc. Natl. Acad. Sci. USA 2009, 106, 19780-19784. [CrossRef]

26. Zheng, Q.J.; Zhang, Y.F.; Montazerian, M.; Gulbiten, O.; Mauro, J.C.; Zanotto, E.D.; Yue, Y.Z. Understanding Glass through Differential Scanning Calorimetry. Chem. Rev. 2019, 119, 7848-7939. [CrossRef]

27. Daguano, J.K.M.E.; Strecker, K.; Ziemath, E.C.; Rogero, S.O.; Fernandes, M.H.V.; Santos, C. Effect of partial crystallization on the mechanical properties and cytotoxicity of bioactive glass from the $3 \mathrm{CaO}$ center dot $\mathrm{P}_{2} \mathrm{O}_{5}-\mathrm{SiO}_{2}-\mathrm{MgO}$ system. J. Mech. Behav. Biomed. 2012, 14, 78-88. [CrossRef] [PubMed]

28. Kleebusch, E.; Patzig, C.; Höche, T.; Rüssel, C. Effect of the concentrations of nucleating agents $\mathrm{ZrO}_{2}$ and $\mathrm{TiO}_{2}$ on the crystallization of $\mathrm{Li}_{2} \mathrm{O}-\mathrm{Al}_{2} \mathrm{O}_{3}-\mathrm{SiO}_{2}$ glass: An X-ray diffraction and TEM investigation. J. Mater. Sci. 2016, 51, 10127-10138. [CrossRef] 
29. Wu, J.Q.; Lin, C.W.; Liu, J.L.; Han, L.; Gui, H.; Li, C.; Liu, T.Y.; Lu, A.X. The effect of complex nucleating agent on the crystallization, phase formation and performances in lithium aluminum silicate (LAS) glasses. J. Non-Cryst. Solids 2019, 521, 119486. [CrossRef]

30. Arvind, A.; Kumar, R.; Deo, M.N.; Shrikhande, V.K.; Kothiyal, G.P. Preparation, structural and thermo-mechanical properties of lithium aluminum silicate glass-ceramics. Ceram. Int. 2009, 35, 1661-1666. [CrossRef]

31. Hou, Z.X.; Zhang, Y.M.; Zhang, H.S.; Zhang, H.B.; Shao, J.; Su, C.H. Study on crystallization and microstructure of $\mathrm{Li}_{2} \mathrm{O}_{-} \mathrm{Al}_{2} \mathrm{O}_{3}-$ $\mathrm{SiO}_{2}$ glass ceramics. J. Univ. Sci. Technol. B 2006, 13, 564-569. [CrossRef]

32. Liu, T.; Li, C.; Huang, Q.; Liu, C.; Lin, C.; Zhang, Q.; Luo, Z.; Zhu, L.; Lu, A. Characterization of structure and properties of $\mathrm{MgO}-\mathrm{Al}_{2} \mathrm{O}_{3}-\mathrm{SiO}_{2}-\mathrm{B}_{2} \mathrm{O}_{3}-\mathrm{Cr}_{2} \mathrm{O}_{3}$ glass-ceramics. J. Non-Cryst. Solids 2020, 543, 120154. [CrossRef]

33. Wang, Q.; Zhang, Q.; Luo, L.; Yan, T.; Liu, J.; Ding, L.; Jiang, W. Effects of high-temperature treatment and iron reduction index on tensile strength of basalt continuous fiber. J. Non-Cryst. Solids 2021, 564, 120836. [CrossRef]

34. Pisciella, P.; Pelino, M. FTIR spectroscopy investigation of the crystallisation process in an iron rich glass. J. Eur. Ceram. Soc. 2005, 25, 1855-1861. [CrossRef]

35. Gy, R. Ion exchange for glass strengthening. Mater. Sci. Eng. B-Adv. 2008, 149, 159-165. [CrossRef]

36. Li, X.C.; Meng, M.; Li, D.; Wei, R.; He, L.; Zhang, S.F. Strengthening and toughening of a multi-component lithium disilicate glass-ceramic by ion-exchange. J. Eur. Ceram. Soc. 2020, 40, 4635-4646. [CrossRef]

37. Seaman, J.H.; Lezzi, P.J.; Blanchet, T.A.; Tomozawa, M. Degradation of ion-exchange strengthened glasses due to surface stress relaxation. J. Non-Cryst. Solids 2014, 403, 113-123. [CrossRef] 